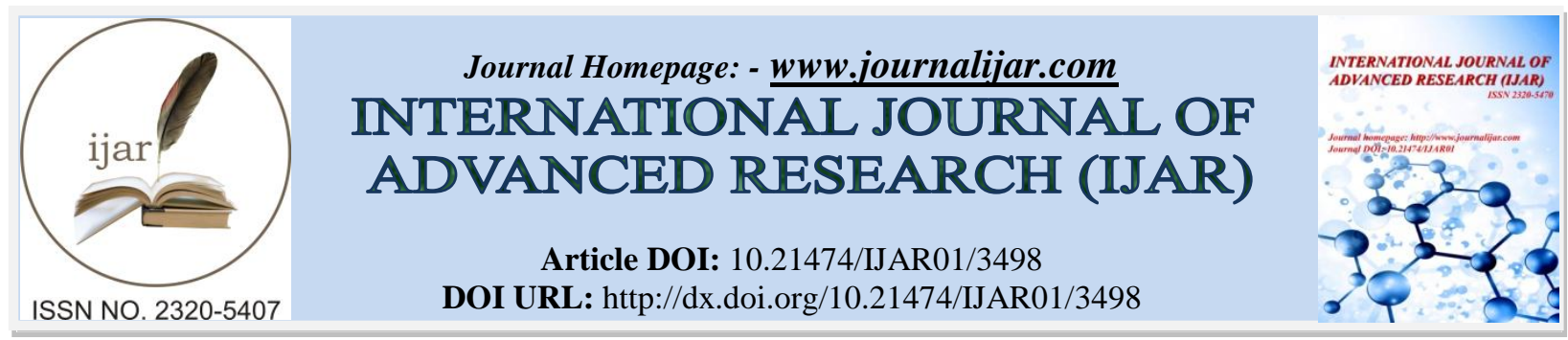

RESEARCH ARTICLE

\title{
PERCEPTION OF DISASTER PREPAREDNESS AMONG EMERGENCY PHYSICIAN IN INDIA.
}

Dr. Sajid Nomani ${ }^{1}$, Dr.Pranab Barua ${ }^{2}$, Dr.Vivek goyal ${ }^{3}$, Dr. Debasis Mishra ${ }^{4}$ and Dr. Imran Khan ${ }^{5}$.

1. Consultant,Dept of Emergency Medicine,AMRI Hospital Bhubaneshwar.

2. Consultant \& In charge,Dept of Emergency Medicine,Ruby hospital,Kolkata.

3. Consultant \& In charge,Dept of Emergency Medicine,Care Hospital,Bhubaneswar.

4. Junior consultant,Dept of Emergency Medicine,AMRI Hospital Bhubaneshwar.

5. Post graduate trainee,Dept of Emergency Medicine,AMRI Hospital Bhubaneshwar.

\section{Manuscript Info}

(..........................

Manuscript History

Received: 15 January 2017

Final Accepted: 13 February 2017

Published: March 2017

Key words:

Disaster, Disaster preparedness, Perception, Emergency physician.

\section{Abstract}

INDIA is a country that's more prone to natural Calamities \& disasters [UNESCO Bangkok, 2007.] .No city in the India can be said to be free from Risk and Hazard of facing such acts.

Disaster is a serious public health issue and one of man's oldest concerns, and we have no control over when and where they happen, but with proper preparedness and planning for all phases of disaster, we can minimize the consequences of any disaster.

In last few decades frequency and intensity of various disasters have been significantly increasing all over the world.

Emergency physicians are main players in disaster responses but their knowledge levels of disaster medicine and their psychosocial status are not readily available. This study aimed to evaluate psychosocial preparedness levels and training needs of disaster medicine among potential disaster responders and presented a necessity to popularize disaster medicine education

Methodology: This study is a survey based descriptive study, to fulfill this purpose a questionnaire was developed and a pilot study was done to validate the questionnaire. A web link for this survey sent through email, to Emergency department directors of varies multispecialty hospitals with accredited emergency department, requesting them to circulate this link among their consultant / postgraduate trainees and residents.

Results: 124 participants from 16 states of India completed this survey over a period of 6 months. Majority of emergency physicians agreed hospitals in India are inadequately prepared to handle various kinds of disasters, whereas around 50\% emergency physicians are not aware of either stockpiles of PPE of their hospitals or their adequacy. Where about $44 \%$ respondents did not know the access to resources in case of emergency events. Interestingly, in the study; around $83 \%$ of

Emergency physicians were ready for being trained in the form of classroom teaching despite their busy schedules, which needs to be appreciated properly.

Conclusion : The study results show that there is enormous scope of further improvement in various aspects of disaster preparedness. 
Though in certain areas the result were satisfactory, majority of the results demand improvement. In the current scenario there is a need for an organized effort for the spread of disaster preparedness amongst the Emergency physician in India. As per the outcome of this study ,it can be concluded that perception of disaster preparedness among Emergency physician in India is still an iceberg phenomenon. Thereby emphasizing upon the fact that hospital administration authorities, government and nongovernmental agencies should take a serious note on it and take measures to inculcate awareness among EPs and should treat finding of this study with seriousness and treat it as a base for further studies for improvement in this field.

Copy Right, IJAR, 2017,. All rights reserved.

\section{Introduction:-}

Disaster is a serious public issue and one of man's oldest concerns, and we have no control over when and where they happen, but with proper preparedness and planning for all phases of disaster, we can minimize the consequences of any disaster.

In last few decades frequency and intensity of various disasters have been significantly increasing all over the world.

Floods, drought, hurricanes and other disasters in last few decades have caused severe environment disruption as well as huge economic losses.

Emergency physicians are main players in disaster responses but their knowledge levels of disaster medicine and their psychosocial status are not readily available. This study aimed to evaluate psychosocial preparedness levels and training needs of disaster medicine among potential disaster responders and presented a necessity to popularize disaster medicine education.

The term DISASTER originated to the French word "Desastre" which is a Combination of two words 'des' meaning bad and 'aster' meaning star. Thus the term refers to 'Bad or Evil star'. '

Disasters usually defined as "A serious disruption in the Functioning of the community or a society causing wide spread material, economic, social or environmental losses which exceed the ability of the affected society to cope using its own resources" $1,2,3$

A disaster is a result from the combination of hazard, vulnerability and insufficient Capacity or measures to reduce the potential chances of risk. ${ }^{3}$

If we think back around 25-30 years, we rarely heard about a major disaster happening, now think in the present context, today it seems like every time we turn around there has been another major disaster.

As an aftermath of the 9/11 World Trade Center, USA event, Attack on Indian parliament on December 13,Indian Ocean tsunami on 24th December 2004 ,Mumbai attack 2009 \& Recent Tsunami in Japan, and several incidence like that around the world and in India, has given a new management of disasters on a large scale, hence the importance of disaster management and disaster preparedness become quite evident even to the layperson.

India is one of the most disaster prone countries of the world ${ }^{4,5}$.

It has had some of the world's most severe droughts, cyclones, chemical disasters, mid-air head-on air collisions, and earthquakes, rail and road accidents. India is also one of the most terrorist prone countries.

According to EM-DAT (2011) report Indian subcontinent acquired fourth position in term of reported disaster, after Philippines, USA, and China. 
India is a huge country and it holds as many variations in religion, language, customs, art and cuisine as it does in topography and hence the disasters vary in their type and magnitude as well.

Disasters are typically viewed as low probability yet high impact events. Although various definitions have been used, a disaster is frequently viewed as a situation in which the number of patients presenting to the medical facility within a given time period exceed the ability of the hospital to provide care without external assistance. As such, the definition is institution specific, and therefore preparedness must be likewise institution specific.

The term "hospital preparedness" is a catch-all phrase, covering a multitude of inter-related areas of medical and non-medical disaster management. Although the Joint Commission on Accreditation of Healthcare Organizations (JCAHO) mandates specific standards for hospital preparedness, in many institutions these standards never extend beyond the written page. Hospital preparedness is focused on either natural or unintentional man-made mass casualty events such as accidents, earthquakes, tornadoes, commercial building collapse, and airline or school bus accidents. ${ }^{5,6}$

Almost $85 \%$ of India's area is vulnerable to one or multiple hazard. Of the 28 states and 7 union territories, 22 are disaster-prone. It is vulnerable to wind storms spawned in the Bay of Bengal and the Arabian Sea, earthquakes caused by active crustal movement in the Himalayan mountains, floods brought by monsoons, and droughts in the country's arid and semi-arid areas. India has also become much more vulnerable to tsunamis since the 2004 Indian Ocean tsunami. ${ }^{7}$

\section{The size and location of our country gives us:}

i. $\quad 57 \%$ of landmass prone to earthquakes (high seismic zones III-V)

ii. $68 \%$ of the total area are vulnerable to drought.

iii. $12 \%$ to floods.

iv. 8000 kilometers' long coastline with an average of two cyclone seasons.

India is a country that's more prone to natural Calamities \& disasters [UNESCO Bangkok, 2007.] .

There is no city or district or village in India can be said to be free from Risk and Hazard of facing such events, hence the responsibility of the people functioning with government as well as private organizations increases manifold.

Beside as citizen of a country which has high risk of both natural and manmade disaster, we all have a certain amount of responsibility for facing and overcoming the socioeconomic as well as psychological impact of these incidents.

The medical impact of any major disaster is felt by the emergency physician and associated staff located within the geographical zone facing the event; they are first people to deal with victims of any disaster, especially Emergency Physician who has to lead a team in such kind of event and facing all challenges along with playing an important role in all phases of disaster, pre-disaster, in-disaster, and post-disaster.

Emergency medical services and emergencies physician should play a leadership role in preparedness activities such as training and education, development of performance metrics, establishment of memorandum of understanding (MOUs), and others planning.

So it is very important that most of the physicians have a good understanding about disaster preparedness. This study aimed to understand what is the current perception about disaster preparedness amongst the Emergency physicians of India. 


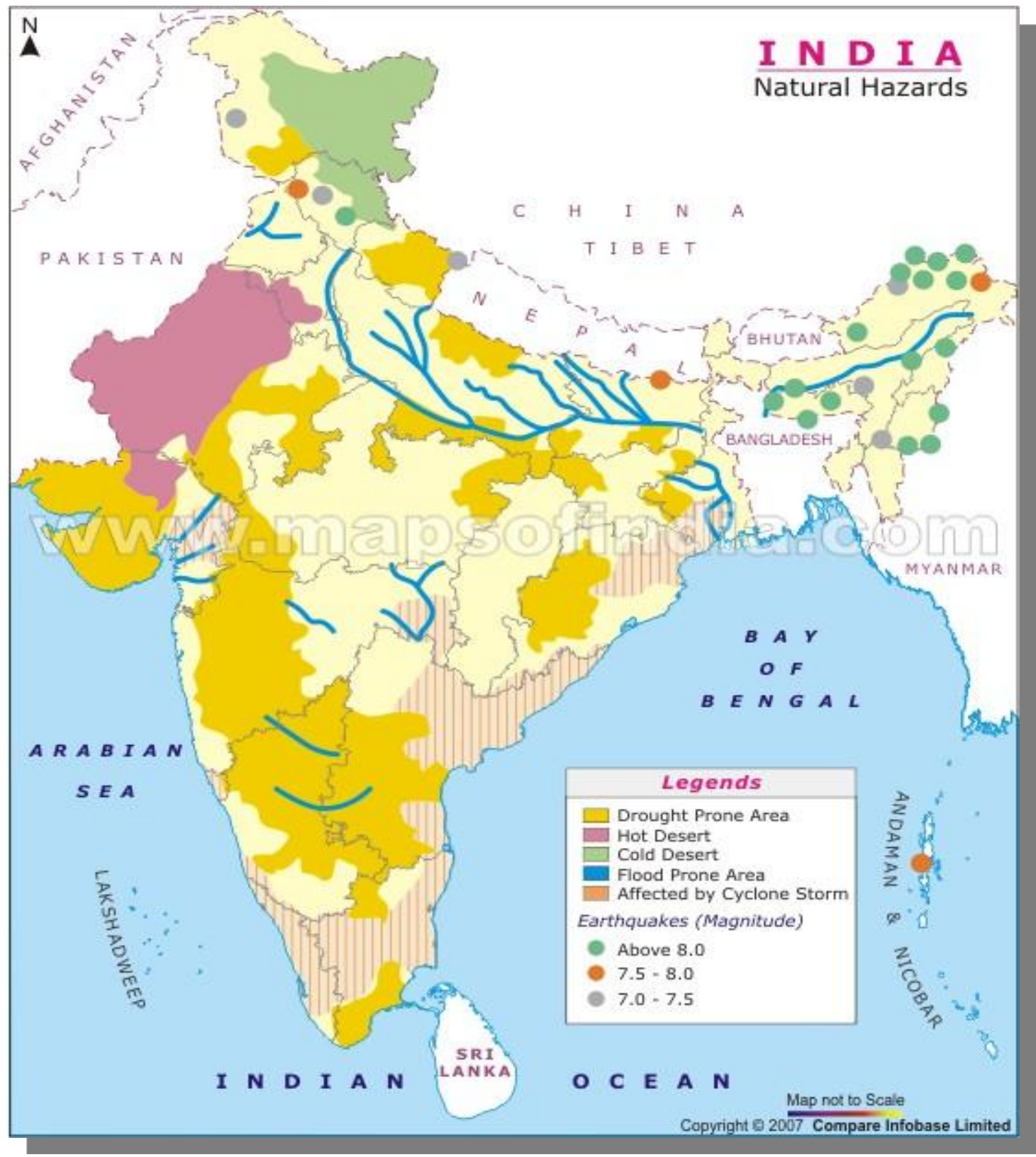

Fig 2.1:- showing Natural disaster prone zone in India. Source: http://www.mapsofindia.com 


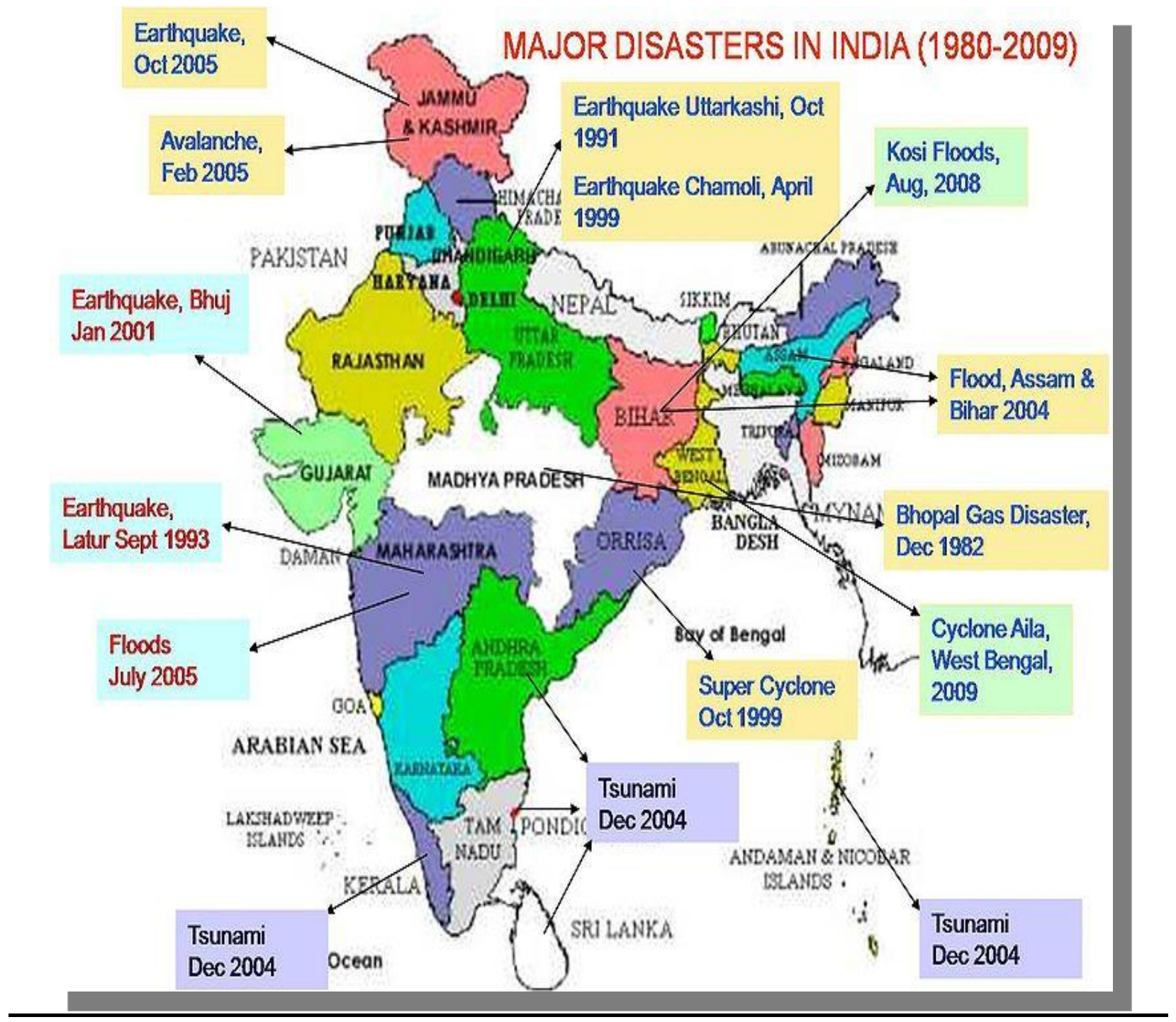

Fig.2.2:- major disasters in India in last 3 decades

\section{Literature Review:-}

Online databases were used to identify relevant studies for this Literature review,

The search was limited to human and English language. Search was restricted between the years 1995 to 2015 in order to provide only recent evidence. No previous study was identified on Emergency Physician's perception about disaster preparedness in India. Though no similar study was identified in the Indian context, the above search identified about 6 trials on nurse's perception, physician perception and preparedness done globally in last two decades, that was relevant to our topic. Also some textbooks and material from the internet were studied for the purpose.

A study was done to investigate Emergency Physicians' knowledge about the Superfund Amendments and Reauthorization Act (SARA) Title III legislation, passed by the United States Congress in 1986, and to determine the factors contributing to their level of preparedness in dealing with patients exposed to toxic chemicals. In this study, author found that out of 187 directors of EDs in New York, only 33\% of the directors had heard about SARA. Despite the finding that some emergency physicians are involved in community preparations, two main problems persist in planning a medical response to environmental emergencies. First, the ED directors generally are unaware of the legislation that mandates these preparations and are not interacting with community planners. Second, there is not full involvement by the local EDs in the Local Emergency Planning Committee's planning efforts. ${ }^{8}$ 
A review of literature suggests that nurse's response to working during a bioterrorism event is not well described. The limited number of studies regarding nurses' concerns, fears, and anxieties is focused on nurses' experiences in natural disaster or war situations. Additional studies are needed to validate the appropriateness of applying findings from disaster response studies to bioterrorism events. During bioterrorism events, nurses will be expected to provide physical care and emotional and psychological support for victims and victims' families. Realistic bioterrorism plans should incorporate strategies to support nurses and address their physical, psychological, and emotional issues. Strategies to optimize safe working conditions and minimize psychological trauma such as technical training regarding bioterrorism agents and debriefing opportunities should be included. ${ }^{9}$

In another study author ranked nurses higher than physicians regarding their knowledge and skills in dealing with mass causality events involving children, but the level of knowledge for mass causality events involving children was low in both. ${ }^{10}$

Another study supported the above by concluding that considerably more training and information are needed to enhance preparedness for frontline healthcare workers (nurses) as important members of the disaster response community. ${ }^{11}$

The importance of physician involvement and leadership in crisis preparedness is recognized by Uddin et al (2008). Their literature also suggests that few physicians are adequately trained to practice effectively in a large-scale crisis situation. $^{12}$

In a recent pilot study on disaster training program to improve emergency physicians' preparedness. They concluded that Disaster preparedness is an essential area of clinical competence for EPs. Participation in a yearlong pilot training program demonstrated a statistically significant increase in cognitive competence among a pilot sample of Emergency Physicians. ${ }^{13}$

The above literature review clearly identifies that, very few physicians are adequately trained to practice effectively in a large-scale crisis situation.

\section{Methodology:- \\ Participants:-}

Participants for this study was consultants Emergency department, emergency department residents, and postgraduate trainees of emergency medicine from varies multispecialty, tertiary care level hospitals of India which have a fully functional Emergency department.

Those doctors who were working other than emergency department were excluded from this study.

\section{Questionnaire:-}

This study is a survey based descriptive study, to fulfill this purpose a 13 items questionnaire was developed including three demographic questions,(from question 1 to question 3) which included participant's gender, age, their professional role, residing state, contact number, and their emails.

Question 5 to question 10 had multiple sub-questions under their heading.

The questionnaire was divided in two part for understanding the following

1. Familiarity regarding specific term and activities in different emergency preparedness categories.

2. Participant's experience and training.

\section{Survey:-}

This survey was conducted through a web based survey site https://www.surveymonkey.net,a web link https://www.surveymonkey.com/s/SK3BPRK sent through email, to Emergency department directors of varies multi specialty hospitals with accredited emergency department, requesting them to circulate this link among their consultant / postgraduate trainees and residents. A multi stage sampling method was use to fulfill the objective of this survey. Apart from web based collection, some sampling was done through printed questionnaire, which was manually entered in website for proper analysis. 


\section{Questions Wise Result:-}

124 participants from 16 states of India completed this survey over a period of 6 months.

99 respondents participated through an online survey tool and 25 participants were directly administrated printed questionnaire.

An accurate estimate of the response rate is difficult to assess, as it was not possible to ascertain, what proportion of emergency physician have indeed been exposed to the email invitation to participate in this survey.

We excluded 10 responses from the final analysis as these were incomplete.

Key demographic characteristics (Q.No.1-3) of the respondents are detailed in following tables.

Table 5.1:- Representing gender distributions.

\begin{tabular}{|l|l|l|l|}
\hline Gender & Male & Female & $\begin{array}{l}\text { Response } \\
\text { Count }\end{array}$ \\
\hline Answer Options & 86 & 28 & 114 \\
\hline Numbers of respondents & 86 & & \\
\hline
\end{tabular}

Table 5.2:- Representing distributions of participant's age group Age( in years)

\begin{tabular}{|l|l|l|l|l|l|l|l|}
\hline Answer Options & $25-30$ & $30-35$ & $35-40$ & $40-45$ & $45-50$ & $>50$ & $\begin{array}{l}\text { Response } \\
\text { Count }\end{array}$ \\
\hline Number of participants & 55 & 15 & 16 & 12 & 9 & 7 & 114 \\
\hline
\end{tabular}

Table 5.3:- Showing distributions in work experience

\begin{tabular}{|l|l|l|l|l|l|l|}
\hline Work Experience in Emergency department(in years) & $0-1$ & $1-5$ & $5-10$ & $10-15$ & $>15$ & $\begin{array}{l}\text { Response } \\
\text { Count }\end{array}$ \\
\hline Answer Options & & & & & & \\
\hline Number of respondents & 31 & 46 & 25 & 12 & 0 & 114 \\
\hline & & & & & & \\
\hline
\end{tabular}

Table 5.4:- Distributions in professional role

\begin{tabular}{|l|l|l|l|l|l|l|}
\hline Professional role & Consultant & $\begin{array}{l}\text { Associate } \\
\text { Consultant }\end{array}$ & $\begin{array}{l}\text { Junior } \\
\text { Consultant }\end{array}$ & PG Student & EMO & $\begin{array}{l}\text { Response } \\
\text { Count }\end{array}$ \\
\hline Number of participant & 24 & 8 & 9 & 69 & 3 & 113 \\
\hline & & & & & & \\
\hline
\end{tabular}

Table 5.5:- Distribution of states

\begin{tabular}{|l|l|l|l|l|l|l|l|l|l|l|l|l|l|l|l|l|l|}
\hline States & A.P & Asm & Bh & Dl & chg & Jh. & Kar & krl & MP & MH & OR & PN & RJ & TL & UP & WB & RC \\
\hline NOR & 6 & 4 & 4 & 18 & 7 & 1 & 11 & 8 & 2 & 9 & 1 & 2 & 2 & 9 & 3 & 27 & 114 \\
\hline & & & & & & & & & & & & & & & & & \\
\hline
\end{tabular}

A.P-Andhrapradesh;Asm-Assam;Bh-Bihar;Chg.-Chandigarh;Del-Delhi:Jh.-Jharkhand;Kar-Karnatka;krl-kerala;MPMadhyaPradesh;MH-Maharashtra;OR-Orisha;PN-Punjab;RJ-Rajsthan;TL-TamilNadu;UP-UttarPradesh;WB-

WestBengal

RC-Response Count;NOR-number of respondents

Among the respondents $76.11 \%$ (86) were male and 23.89\% (27) were female.

$48.67 \%$ (56) were aged between $25-30$ years,

$5.31 \%$ (6) were aged more than 50 years, rest of the respondents were aged between 30 to 50 years. 
Of the 114 respondents, majority $61.06 \%$ (69) were postgraduate emergency medicine residents, while $21.24 \%$ (24) were working as consultant(s) in emergency department. and a small portion of respondents were working as junior consultants $7.96 \%(9)$, Associate consultant 7.08\%(8) and 2.65\%(3) working as emergency medical officer.

Majority of respondents $40.35 \%$ (46) had working experience ( in the emergency department) between 1-5 years. $33.67 \%$ (33) had only 0-1 year working experience; while there is $13.27 \%(13)$ respondents had 5-10 years of experience, and only $4.27 \%$ (4) had more than 10 years of working experience in the emergency department .

Q.4: Familiarity with Emergency Preparedness Terms \& Activities.

Table 5.6:- showing details percentage of familiarity with term and activities of emergency preparedness.

\begin{tabular}{|c|c|c|c|c|c|c|}
\hline Answer Options & $\begin{array}{l}\text { Not } \\
\text { familiar }\end{array}$ & $\begin{array}{l}\text { Somewhat } \\
\text { familiar }\end{array}$ & Familiar & $\begin{array}{l}\text { Very } \\
\text { familiar }\end{array}$ & $\begin{array}{l}\text { Rating } \\
\text { Average }\end{array}$ & $\begin{array}{l}\text { Response } \\
\text { Count }\end{array}$ \\
\hline $\begin{array}{l}\text { Familiarity with triage in large scale } \\
\text { emergency event }\end{array}$ & 2 & 33 & 49 & 30 & 2.94 & 114 \\
\hline $\begin{array}{l}\text { Assess and Respond to site safety } \\
\text { issue for self, co-worker, \& victim } \\
\text { during a emergency event }\end{array}$ & 10 & 26 & 49 & 27 & 2.83 & 112 \\
\hline $\begin{array}{l}\text { Please provide an assessment of } \\
\text { your overall familiarity with } \\
\text { response activity/preparedness in the } \\
\text { case of a large scale emergency } \\
\text { event }\end{array}$ & 7 & 36 & 60 & 11 & 2.66 & 114 \\
\hline $\begin{array}{l}\text { Your hospital preparedness for } \\
\text { responding to a large scale } \\
\text { emergency event }\end{array}$ & 10 & 40 & 50 & 14 & 2.60 & 114 \\
\hline $\begin{array}{l}\text { Overall familiarity with } \\
\text { sign/symptoms of exposure to } \\
\text { different biological agent/contagious } \\
\text { disease outbreak }\end{array}$ & 18 & 38 & 47 & 8 & 2.41 & 111 \\
\hline $\begin{array}{l}\text { Familiarity } \\
\begin{array}{l}\text { with } \\
\text { operations } \\
\text { hospital }\end{array}\end{array}$ & 19 & 56 & 32 & 6 & 2.22 & 113 \\
\hline $\begin{array}{l}\text { Familiarity with incident command } \\
\text { system(ICS) }\end{array}$ & 27 & 26 & 36 & 24 & 2.50 & 113 \\
\hline $\begin{array}{l}\text { Familiarity with rapid assessment of } \\
\text { victim of emergency event }\end{array}$ & 4 & 15 & 56 & 38 & 3.13 & 113 \\
\hline $\begin{array}{lrr}\text { Familiarity } & \text { with } & \text { your } \\
\text { facility's/community } & \text { quarantine } \\
\text { process } & & \\
\end{array}$ & 31 & 50 & 24 & 7 & 2.06 & 112 \\
\hline $\begin{array}{l}\text { Use of all type of communication } \\
\text { devices(fax/email/satelite ph.) }\end{array}$ & 6 & 27 & 22 & 59 & 3.18 & 114 \\
\hline \multicolumn{6}{|l|}{ answered question } & 114 \\
\hline \multicolumn{6}{|l|}{ skipped question } & 0 \\
\hline
\end{tabular}

The first question in this section was on familiarity with triage in a large scale emergency event. 42.98\% (49) showed that they are familiar with triage, and $28.95 \%$ (33) respondents denoted that they are somewhat familiar ,26.32\%(30)respondents replied that they are very familiar with triage in large emergency event while, only $1.75 \%(2)$ were not aware about triage in large emergency event.

Out of 114 respondents $43.75 \%$ (49) denoted that they are familiar with self safety and site safety issues, 24.11\%(27) think that they are very familiar with safety issues and a small percentage $8.93 \%(10)$ said that they are not familiar with site safety issue for self and co-workers during emergency events.

When asked about familiarity with sign and symptoms of exposure to different biological agent/contagious diseases outbreak, 42.34\%(47) said that they are familiar, and 34.23\% (38)replied "somewhat familiar", while 16.22\% 
(18)were not familiar and only a small group of respondents $7.21 \%$ (8) were confident and very familiar with this issue.

Majority of respondents $49.56 \%$ (56) said that they are somewhat familiar with their hospitals emergency operation plan(EOP), 28.32\% (32) respondents thinks that they are familiar, and $16.81 \%$ (19) respondents denoted that they are not familiar with their hospital's EOP. Only 5.31\% (6) were confident in their knowledge regarding hospital EOP.

In assessment of another important component of emergency preparedness the Incident Command System (ICS ) we looked at familiarity with this concept and found that $31.86 \%(36)$ respondents were familiar with ICS, and only $21.24 \%(24)$ of total participants said that they are very familiar with ICS, while a significant percentage of $23.89 \%$ (27) of the respondents denoted that they do not know about ICS. When asked about familiarity with communication devices, majority of $51.75 \%$ (59), shows that they are very familiar with use of the all kind of communication devices.

Q.5: Rate your responses to your hospitals preparedness.

Table 5.7:- details percentage of hospital preparedness to varies kind of emergency events.

\begin{tabular}{|c|c|c|c|c|c|c|}
\hline Answer Options & $\begin{array}{l}\text { No } \\
\text { Preparedness }\end{array}$ & $\begin{array}{l}\text { Inadequately } \\
\text { Prepared- } \\
\text { ness }\end{array}$ & $\begin{array}{l}\text { Adequately } \\
\text { Prepared- } \\
\text { ness }\end{array}$ & $\begin{array}{l}\text { Do } \\
\text { not } \\
\text { know }\end{array}$ & $\begin{array}{l}\text { Rating } \\
\text { Average }\end{array}$ & $\begin{array}{l}\text { Response } \\
\text { Count }\end{array}$ \\
\hline $\begin{array}{l}\text { Do you think hospitals in } \\
\text { India are prepared for } \\
\text { disaster }\end{array}$ & 17 & 87 & 6 & 4 & 1.97 & 114 \\
\hline $\begin{array}{l}\text { Do you think your hospital } \\
\text { is prepared for disaster. }\end{array}$ & 11 & 67 & 29 & 6 & 2.27 & 113 \\
\hline $\begin{array}{l}\text { What is level of } \\
\text { preparedness of your } \\
\text { hospital for bioterrorism? }\end{array}$ & 72 & 20 & 6 & 16 & 1.70 & 114 \\
\hline $\begin{array}{l}\text { What is level } \\
\text { preparedness of } \\
\text { hospital } \\
\text { radiologic/nuclear } \\
\text { incident? }\end{array}$ & 71 & 18 & 6 & 19 & 1.76 & 114 \\
\hline $\begin{array}{l}\text { What is level of } \\
\text { preparedness of your } \\
\text { hospital for infectious } \\
\text { disease outbreaks? }\end{array}$ & 16 & 47 & 44 & 7 & 2.37 & 114 \\
\hline $\begin{array}{lrr}\text { What is level } & \text { of } \\
\text { preparedness of } & \text { your } \\
\text { hospital } & & \text { for } \\
\text { flood/cyclones? } & \\
\end{array}$ & 16 & 37 & 51 & 10 & 2.48 & 114 \\
\hline $\begin{array}{l}\text { What is level of } \\
\text { preparedness of your } \\
\text { hospital for earthquakes? }\end{array}$ & 19 & 31 & 49 & 15 & 2.53 & 114 \\
\hline $\begin{array}{l}\text { What is level of } \\
\text { preparedness of your } \\
\text { hospital for in hospital } \\
\text { terrorist attack? }\end{array}$ & 34 & 35 & 28 & 17 & 2.26 & 114 \\
\hline $\begin{array}{l}\text { What is level of } \\
\text { preparedness of your } \\
\text { hospital in hospital hazmat } \\
\text { accident? }\end{array}$ & 25 & 44 & 31 & 14 & 2.31 & 114 \\
\hline \multicolumn{6}{|l|}{ answered question } & 114 \\
\hline \multicolumn{6}{|l|}{ skipped question } & 0 \\
\hline
\end{tabular}


This section deals with hospital preparedness to varies kind of emergency events.

Majority of respondents $76.32 \%(87)$ agreed that hospital in India are inadequately prepared to handle disasters; $14.91 \%$ (17)said that there is no preparedness amongst Indian's hospital to face large scale emergency events; while a small percentage $5.26 \%(6)$ of respondents think that hospital in India are adequately prepared for disasters.

When asked about participant's hospital disaster preparedness majority $59.29 \%(67)$ agreed that their hospital is inadequately prepared to face large scale emergency events, and 25.66\%(29) of respondents think that their hospital is adequately prepared, while only $9.73 \%$ (11)think that their hospital is not prepared for facing disasters.

Majority of $63.16 \%(72)$ and $62.28 \%(71)$ emergency physician thinks that their hospital is not prepared for bioterrorism activities and radio/nuclear incident respectively, and only a small percentage 5.26 \%( 6) respondents said that they are adequately prepared for both events.

$44.74 \%$ ( 51) emergency physicians thinks that their hospitals are adequately prepared for flood/cyclone and $42.98 \%(49)$ replied that their level of preparedness is adequate for earthquakes.

Q. 6: Rate your responses to Accessing critical resources \& Stockpiles.

Table 5.8:- Represents emergency physicians knowledge about availability of varies stockpiles in their hospital

\begin{tabular}{|l|l|l|l|l|l|}
\hline Answer Options & No & Yes & $\begin{array}{l}\text { Don't } \\
\text { know }\end{array}$ & $\begin{array}{l}\text { Rating } \\
\text { Average }\end{array}$ & $\begin{array}{l}\text { Response } \\
\text { Count }\end{array}$ \\
\hline $\begin{array}{l}\text { Do you know about yours hospital's stockpiles of } \\
\text { personal protective equipments? }\end{array}$ & 58 & 35 & 21 & 1.68 & 113 \\
\hline $\begin{array}{l}\text { Do you know about yours hospital's stockpiles of } \\
\text { personal pmergency } \\
\text { medication/antidotes? }\end{array}$ & 54 & 42 & 18 & 1.69 & 113 \\
\hline $\begin{array}{l}\text { Do you know about yours hospital's stockpiles of } \\
\text { oxygen/electricity backup? }\end{array}$ & 39 & 47 & 27 & 1.89 & 113 \\
\hline $\begin{array}{l}\text { Do you think your hospital has adequate stockpiles? } \\
\text { Do you know that, during an event, where to } \\
\text { quickly access up-to-date resources about specific } \\
\text { (Radiological,Chemical,Nuclear,Biological,and } \\
\text { Explosive) agents }\end{array}$ & & 31 & 56 & 2.21 & 113 \\
\hline answered question & & 31 & 113 \\
\hline skipped question & & & \\
\hline
\end{tabular}

Large number of emergency physician 50.44\%(58) and 46.90\% (54) are not aware about stockpiles of personal protective equipments (PPE) and emergency medication/antidotes respectively in their hospital, while 30.97\% (35) and $37.17 \%$ (42) said they knows about stockpiles of PPE and medication of their hospital.

When asked whether available stockpiles is adequate or not most emergency physician 49.56\%(56) has no idea about this as they replied they do not know, and $28.32 \%$ (33) responded that the available stockpiles is not adequate and $22.12 \%(25)$ emergency physician thinks that their hospital has adequate stockpiles of PPE and emergency medications. Out of 114 respondents $44.25 \%$ (51) replied that they don't know, from where to quickly access up-todate resources about specific agent (radiological/chemical/biological /explosive) and $28.32 \%$ (32) people know about this, while $27.43 \%$ ( 31) of emergency physician has no idea about this as their answer was "do not know". 


\section{Q. 7: Do you feel adequately equipped to work during various kinds of disaster?}

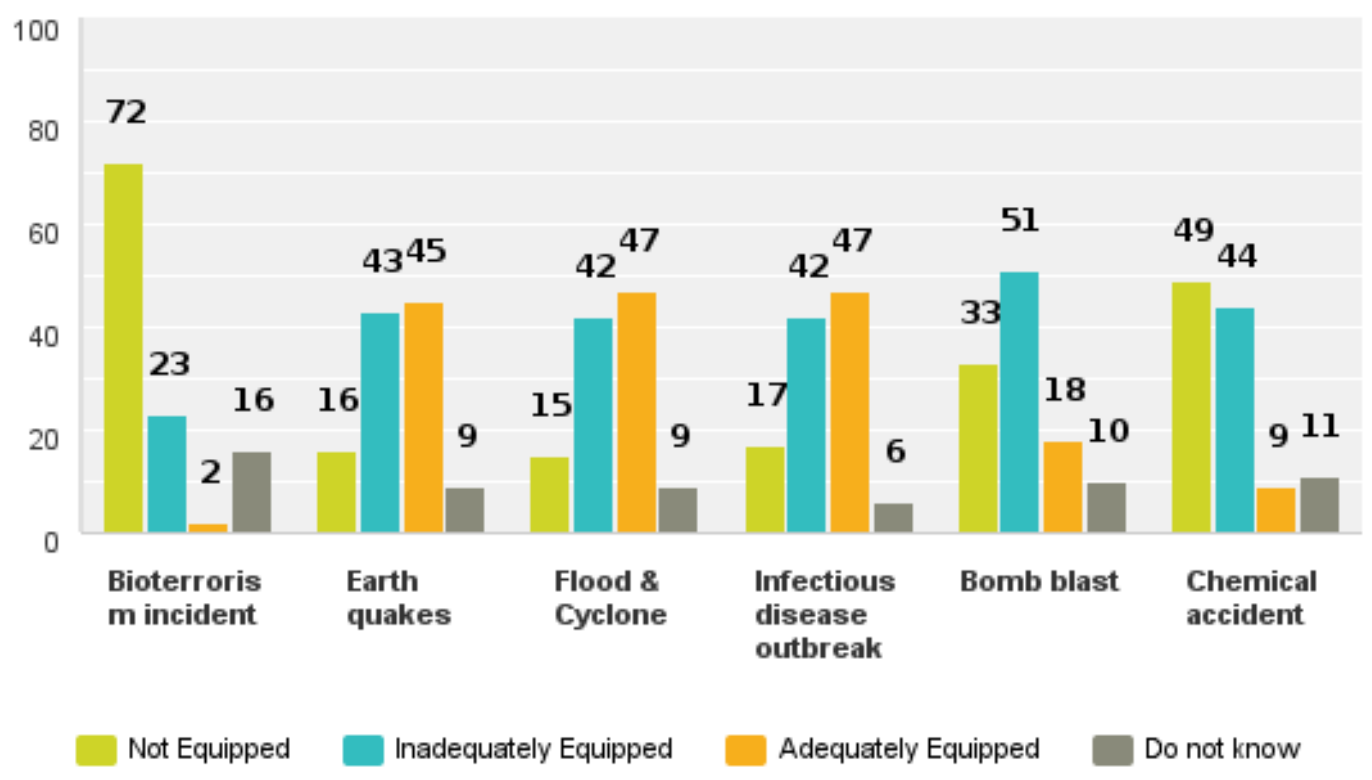

Fig 5.1:- percentage of emergency physician's perception about how well they are equipped, working in different type of disaster.

In this section we tried to access that how well Emergency physicians are equipped working in different type of disaster.

A majority of $63.72 \%$ (72)thought they are not equipped to work in case of bioterrorism event, while $20.35 \%$ (23)thinks inadequately equipped and only $1.77 \%(2)$ respondents replied that they feel adequately equipped.

$39.82 \%(45)$ thought that they are adequately equipped to work in a earthquake event, and $41.59 \%(47)$ replied that they are adequately equipped for flood/cyclone.

In case of bomb blast injuries $45.54 \%$ (51) and $29.46 \%$ (33) of the participants replied that their hospital(s) were 'inadequately equipped' and 'not equipped' respectively, while $16.07 \%(18)$ replied that they were adequately equipped. Only $7.96 \%$ (9) respondents think that they are adequately equipped to face any bomb blast event.

When asked about an infectious outbreak $41.96 \%$ (47) emergency physicians said that they are adequately equipped for working in an infectious outbreak, and 37.50(42)replied that they are inadequately equipped. A major number of respondents $43.36 \%$ (49) replied that they are not equipped for working in a chemical accident, while $38.94 \%(44)$ said they are inadequately equipped. 
Q.8 : Do you feel adequately trained to work during various kinds of disaster?

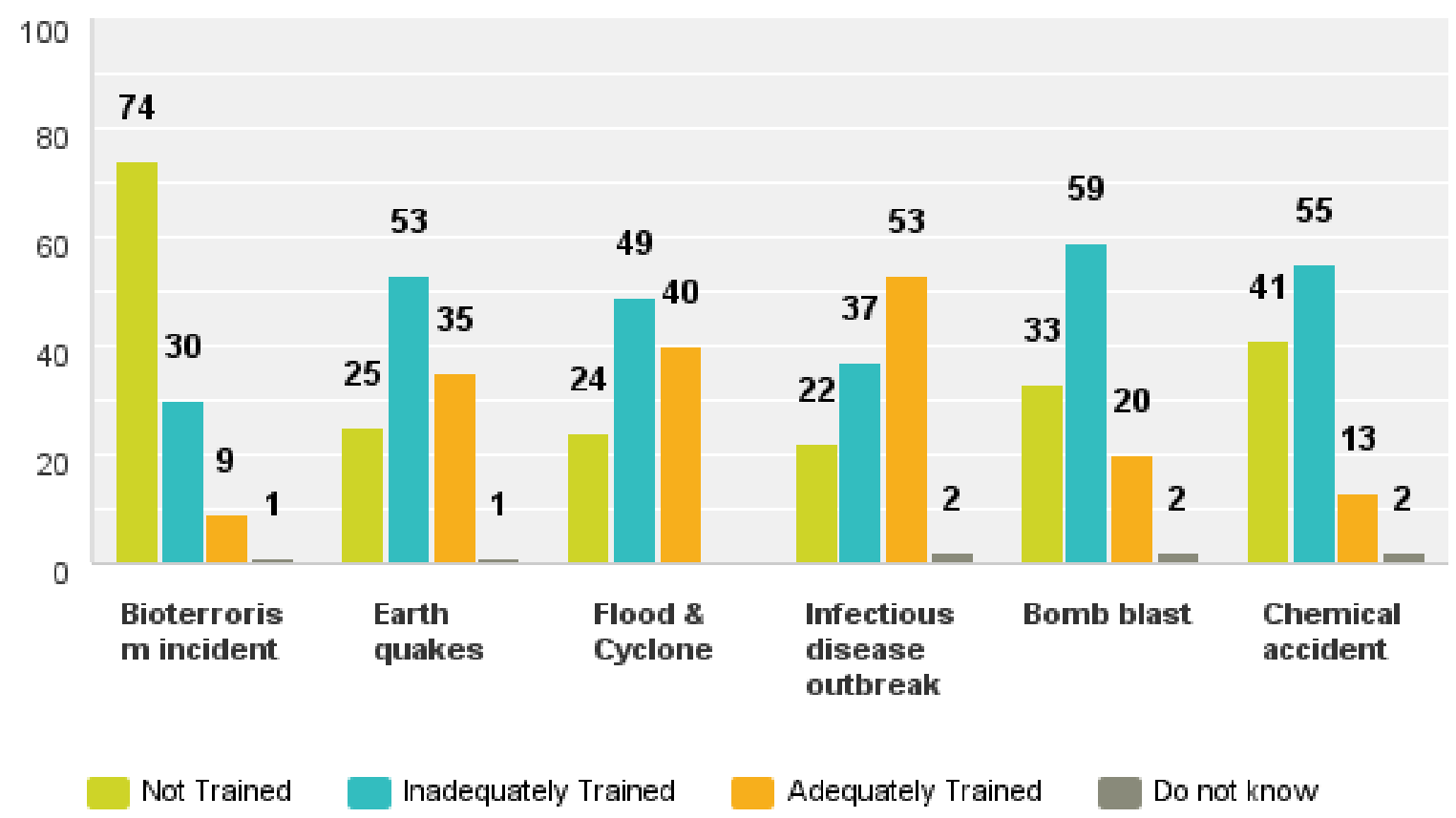

Fig5.2:- shows emergency physician's formal training on different kind of Disasters

Majority of the responding emergency physicians $64.91 \%(74)$ and $36.94 \%(41)$ have stated that they are not trained for working during bioterrorism and chemical accident respectively. While $26.32 \%$ (30)and $49.55 \%(55)$ denoted that they are inadequately trained for working in event of bioterrorism and chemical accident.

A small percentage of $7.89 \%(9)$ and $11.71 \%$ (13)said they are adequately trained for working during such events. Majority of emergency physician 51.75\% (59)said they are inadequately trained for working in a case of bomb blast event, and $28.95 \%$ (33)confirmed that they are not trained for working in bomb blast event(s), while $17.54 \%(20)$ were confident about the adequacy of their training for working on a event of bomb blast. Regarding training for working during earth quakes and flood/cyclone $46.49 \%(53)$ and $43.36 \%(49)$ respectively stated that they were not adequately trained.

$35.40 \%$ (40) emergency physician stated that they are adequately trained for working during flood/cyclone, and $30.70 \%$ ( 35) confirmed their adequate training for working during an earth quake.

$46.49 \%$ ( 53) respondents were confident about the adequacy in their training for working during an infectious disease outbreak.

A significant number of emergency physician $32.46 \%$ (37) denoted their training was inadequate for working during an infectious outbreak; while $19.30 \%(22)$ stated that they are not trained for working in such a scenario. 
Q.9 : Rate your responses to your experience \& training.

Table 5.9:- details of emergency physician's work experience in disastrous events and hospital's disaster plan and policies

\begin{tabular}{|c|c|c|c|c|}
\hline Answer Options & No & Yes & $\begin{array}{l}\text { Rating } \\
\text { Average }\end{array}$ & $\begin{array}{l}\text { Response } \\
\text { Count }\end{array}$ \\
\hline Have you had any training in disaster medical response? & 39 & 75 & 1.66 & 114 \\
\hline $\begin{array}{l}\text { Have you had any experience in working during mass casualty } \\
\text { event? }\end{array}$ & 38 & 76 & 1.67 & 114 \\
\hline $\begin{array}{l}\text { Have you had any experience in working during mass infectious } \\
\text { disease outbreaks? }\end{array}$ & 75 & 39 & 1.34 & 114 \\
\hline $\begin{array}{l}\text { Do you know in case of a disaster who commands the disaster } \\
\text { response in your hospital? }\end{array}$ & 42 & 72 & 1.63 & 114 \\
\hline $\begin{array}{l}\text { Does your hospital have a plan and policies to respond to a large } \\
\text { scale mass causality incident? }\end{array}$ & 35 & 77 & 1.69 & 112 \\
\hline Did your hospital have a fire/disaster drill? & 15 & 97 & 1.87 & 112 \\
\hline $\begin{array}{l}\text { Have you had any experience in working during mass casualty } \\
\text { event? }\end{array}$ & 40 & 71 & 1.64 & 111 \\
\hline Have you been trained on the disaster plan? & 47 & 64 & 1.58 & 111 \\
\hline $\begin{array}{l}\text { As an emergency physician do you think that you will be legally } \\
\text { liable by the Indian legal system for practicing altered level of care } \\
\text { because of limited supply of resources, excessive loads of patients, } \\
\text { as usually happens during disasters? }\end{array}$ & 50 & 63 & 1.56 & 113 \\
\hline \multicolumn{4}{|l|}{ answered question } & 114 \\
\hline \multicolumn{4}{|l|}{ skipped question } & 0 \\
\hline
\end{tabular}

This section deals with Emergency physician work experience in disastrous events and hospital's disaster plan and policies.

Majority of the respondents $65.79 \%(75)$ stated that they have received formal training for working during an external disaster; while $34.21 \%$ (39) were untrained.

$66.67 \%$ (76) emergency physicians had experience working in a mass causality event.

When asked about their experience of working during infectious disease outbreak, majority of $65.79 \%$ (75) of the emergency physician stated that they have never worked in an infectious outbreaks.

when inquire about their hospital's plan and policies of mass causality events and incident commander of their hospital $68.75 \%$ (77) and $63.16 \%$ (72),respectively said that they know about these while $31.25 \%(35)$ and $36.84 \%$ (42) emergency physicians stated that they are unaware about their hospital's disaster plan and policies and incident commander of their hospital.

A large number of emergency physician $86.61 \%(97)$ agreed that their hospital conducts simulation/disaster/fire drill, and $13.39 \%(15)$ replied ' $\mathrm{NO}$ '. to this question.

Majority of respondent $57.66 \%$ (64) had training on hospital disaster plan in their hospital and but a significant percentage $42.34 \%$ (47) of emergency physician did not receive any formal training on disaster management plan.

$55.75 \%$ (63) emergency physician thinks that they are legally liable by "Indian legal system" for practicing altered level of care in emergency events because of limited supply and excessive loads of victims. While $44.25 \%$ (50) said they are NOT legally liable. 


\section{Q.10 : How far would you be willing to travel if a disaster occurred today?}

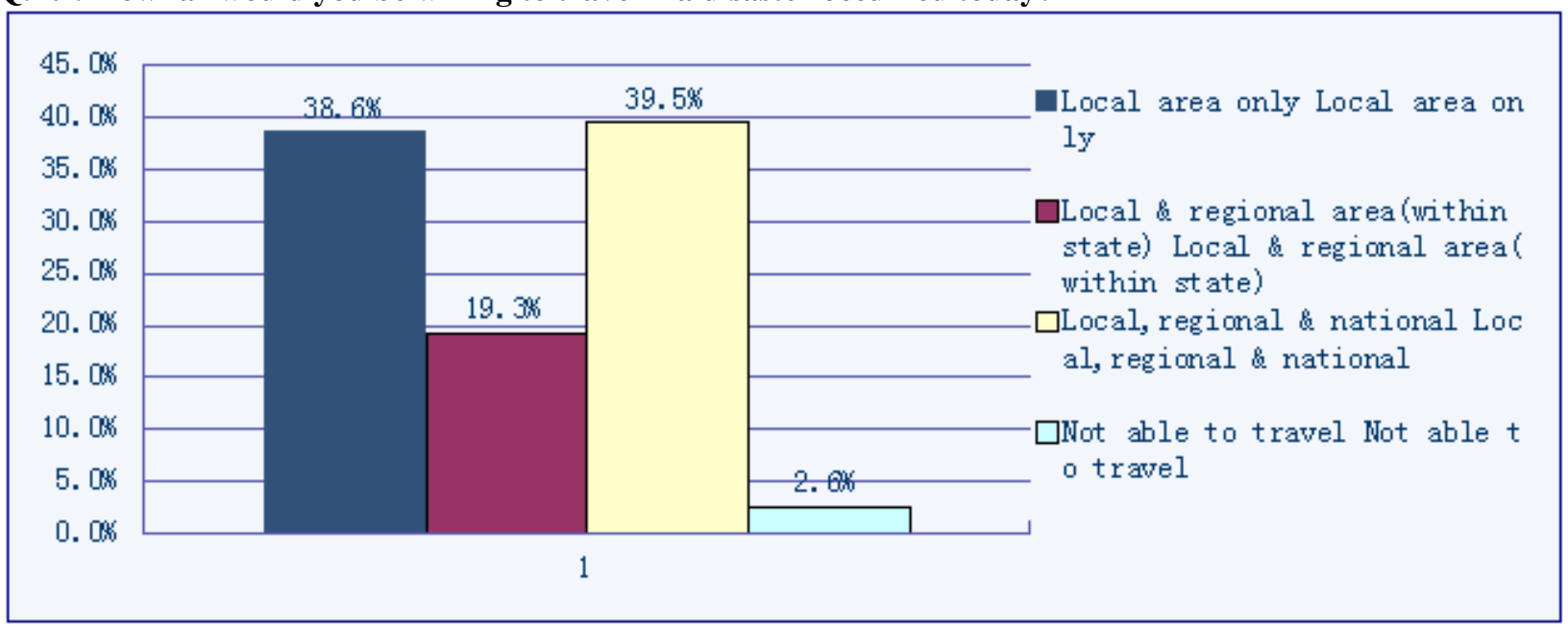

Fig 5.3:- -explaining about willingness of travel to work in case of disaster.

Only 39.50\% (45) emergency physician agreed to travel nationwide to work in disastrous event,and 38.60\%(44) said they can travel only locally. While a small number of $2.63 \%$ (3) respondents were not keen to travel to work in disaster.

Q.11 : How many times in a year your hospital/organization conducts fire drill/simulation drill ?

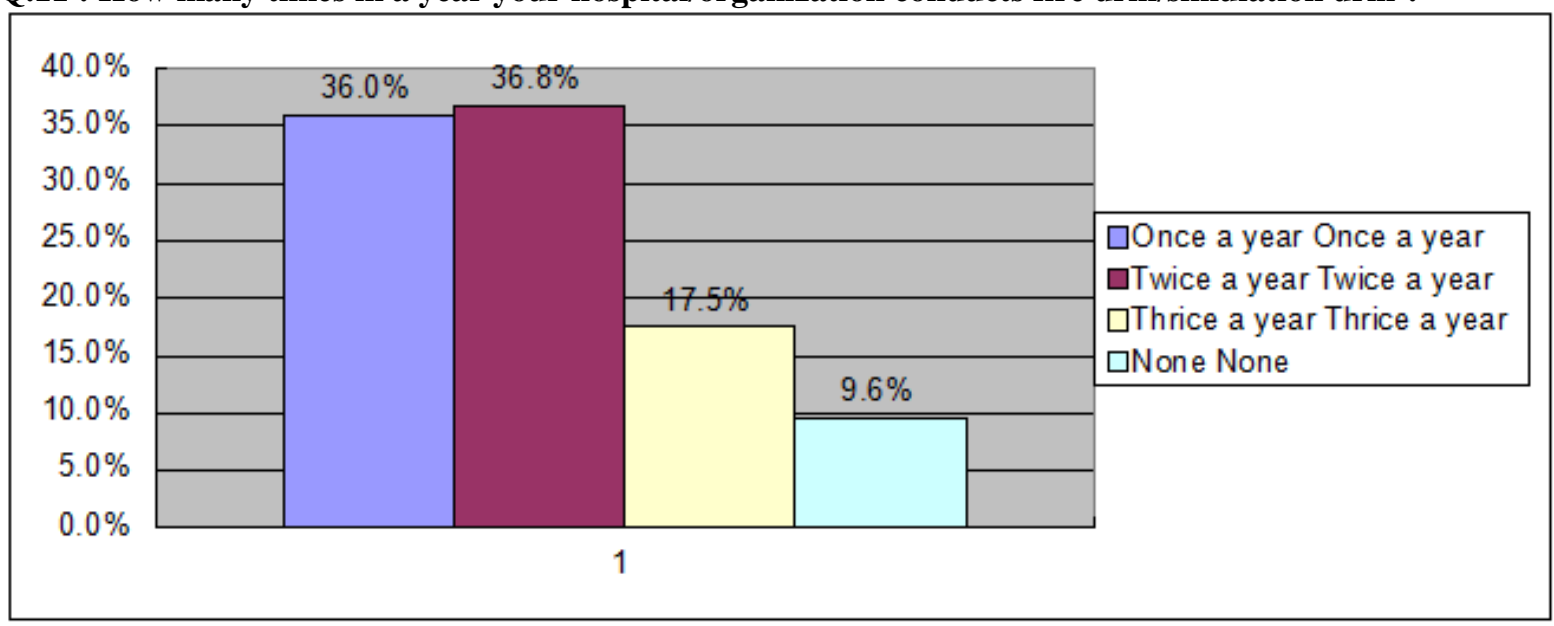

Fig 5.4:- Explaining about simulation drills at participant's hospitals. 
Q.12: When did you last seek information on disaster medical response?

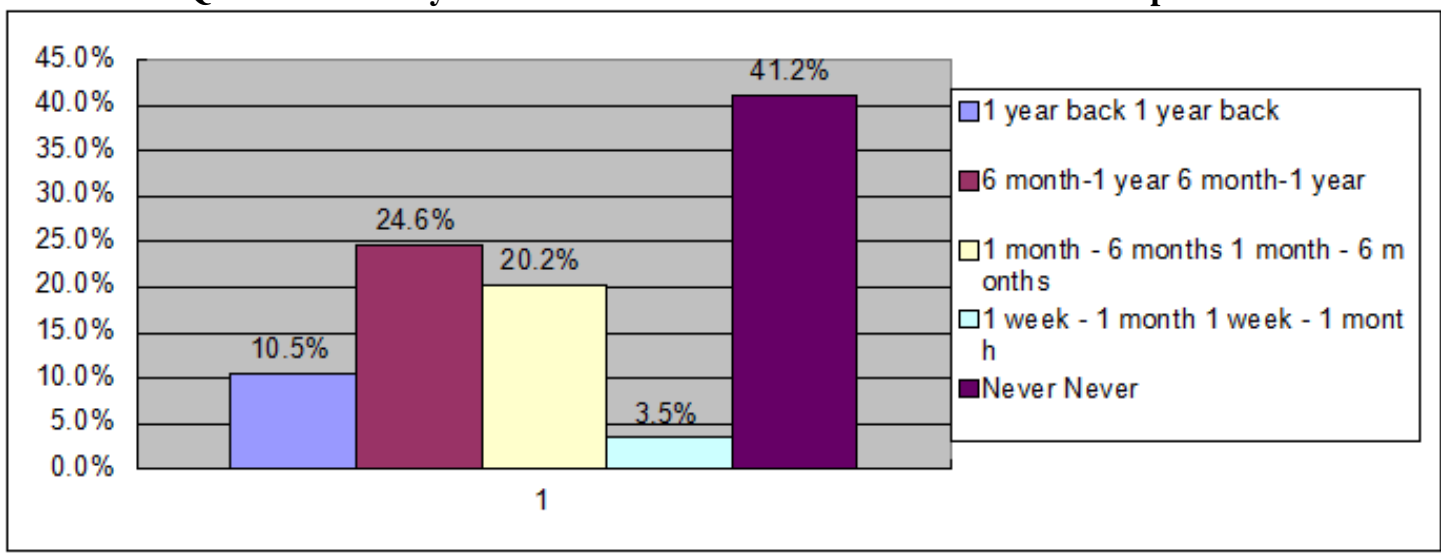

Fig.5.5:- Participant's last gathered information on disaster medical response.

Q. 13 : Your preferred methods to receive emergency preparedness training?

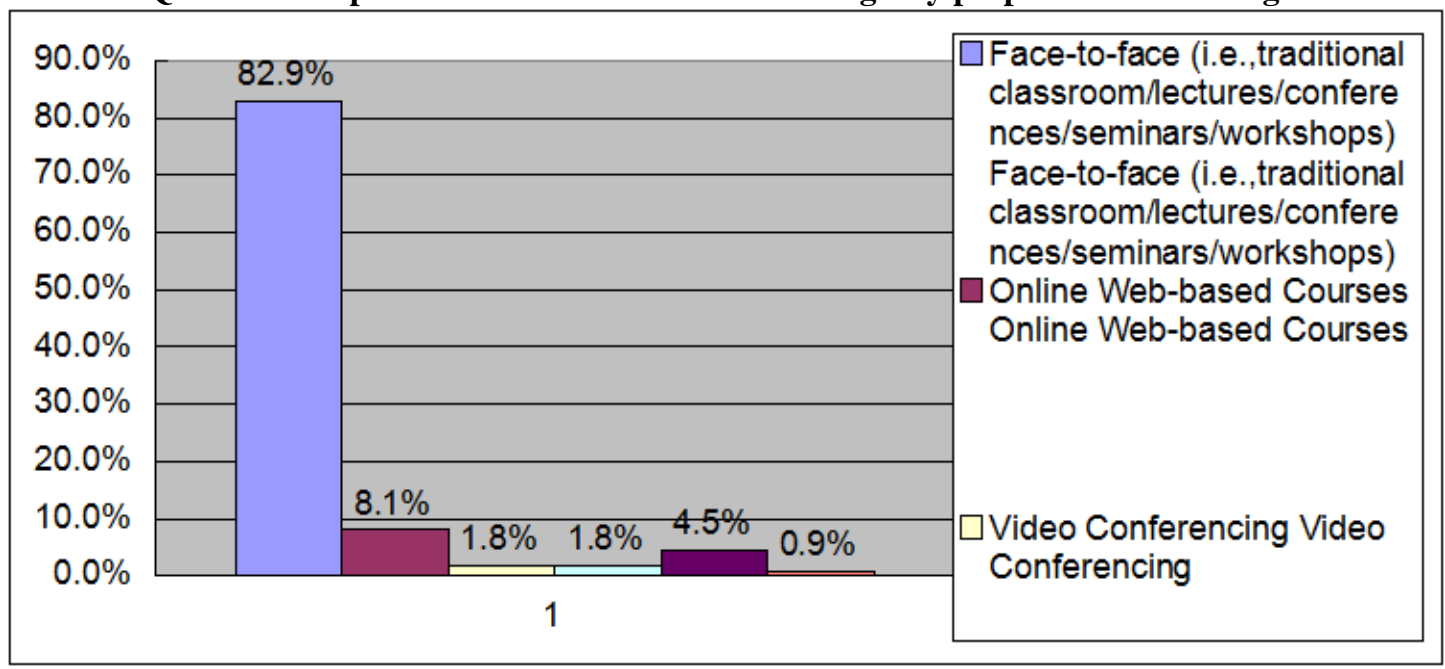

Fig 5.6:- Emergency physician's preferred method of training

A significant number of $41.23 \%(47)$ participants agreed that they never sought information regarding medical disaster response.(fig 5.5)

$82.90 \%$ emergency physicians are ready to take training on disaster response by traditional face to face method, while others are interested in others methods like web based courses, CV/DVD, or pocket reference books.(fig.5.6)

\section{Discussion:-}

Emergency medicine is a broad specialty comprising of disaster medicine as one of its vital branches.

The knowledge of disaster medicine is a paramount importance among the emergency physicians playing the responsibilities of dealing with different kinds of calamities occurring in society.

Natural and human-induced disasters have significantly increased in last few decades which inturn called attention to the fact that emergency physicians play pivotal role in disaster planning.

Though emergency physician are involved in planning, mitigation, response, and recovery aspects of disasters as well as actively participating in actual disaster events, mock drills and further educational opportunities, specific to disaster preparedness; data regarding their knowledge level are not readily available.

This has led to the essence of a pioneer research work to assess "Perception of disaster preparedness among emergency physician in India" 
This unique analysis of perception of disaster preparedness amongst the working emergency physician was conducted on pan India basis among 16 states over a period of 6 months, with a total 124 participants. The study questionnaires were divided in to several subsections which covered various aspects and facts of disaster preparedness.

The result has revealed several interesting findings. The salient features are as follows.. $26 \%$ of emergency physicians were found to be familiar with triage in large emergency event and a significant percentage of them,(around 24\%) did not know about ICS ,an important aspect of disaster preparedness. This is the grey zone with enormous scope of improvement.

Majority of emergency physicians ( around 76\% ) agreed that hospitals in India are inadequately prepared to handle various kinds of disasters, whereas around 50\% emergency physicians are not aware of either stockpiles of PPE of their hospitals or their adequacy. Where about $44 \%$ respondents did not know the access to resources in case of emergency events. Thereby emphasizing upon the fact that hospital administration authorities should take a serious note on it and take measures to inculcate awareness among EPs.

On the other hand, Only 5.26\% emergency physicians thought that their hospitals were adequately prepared to handle a bioterrorism activity as well as radio/nuclear incidents, while around $63 \%$ had an opposite view on the same.

When we tried to gather information that whether they are adequately equipped or not to work in various disastrous events, majority of emergency physicians (around 64\% ) stated that their hospitals were not equipped to work in case of bioterrorism event, while around $40 \%$ and $42 \%$ thought that they are adequately equipped to work in earthquake and flood/cyclone respectively. Only a small percentage ,around $16 \%$ emergency physicians thought that their hospitals were adequately equipped to work in case of bomb blast injuries. On the contrary, other participants replied that either they are inadequately equipped or not equipped. The reason for such differences in views should be sorted out in a systematic way and should be addressed in a proper way accordingly. Thus opening an opportunity for further scientific study on the topic.

When enquired about their formal training dealing with various kinds of disasters, only around $8 \%$ and $12 \%$ were adequately trained in bioterrorism and chemical accident management respectively, where about only $18 \%$ were confident about adequacy of their training for working in bomb blast scenarios. Most of these participants were either working as consultant or having 5-10 years of working experiences in Emergency Medicine.

In due course, around $42 \%$ of Emergency physicians revealed that they did not receive any formal training on the hospital disaster management plan.

When asked, around 40\% Emergency physicians were prepared to travel nationwide to contribute in the management of disastrous events.

Interestingly, in the study; around $83 \%$ of Emergency physicians were ready for being trained in the form of classroom teaching despite their busy schedules, which needs to be appreciated properly.

\section{Limitations:-}

This study is limited to those who have access to internet because this is a questionnaire based survey .

This survey was limited to major cities of India. There are emergency physicians working peripherally in the interiors of India , who are possibly working in more ouster conditions and facing natural calamities more closely .It would be really interesting to know their perception on disaster preparedness.

\section{Conclusion:-}

Emergency physicians are forefront for dealing with disasters its consequences; they are important cadre of any hospital and society, as they play important role in all phases of disaster.

The study results show that there is enormous scope of further improvement in various aspects of disaster preparedness. Though in certain areas the result were satisfactory ,majority of the results demand improvement. In 
the current scenario there is a need for an organized effort for the spread of disaster preparedness amongst the Emergency physician in India. The administrative authorities should treat these results with seriousness and treat it as a base for further studies for improvement in this field.

As per the outcome of the study, it can be concluded that the perception of disaster preparedness in Emergency Physicians of India is still showing an iceberg phenomenon. The level of understanding is still at primordial level, which needs proper standardization to meet the requirements of international standards. This is only feasible by following a proper scientific method to raise awareness among the Emergency Physicians of India \& organizing regular mock drills as well as workshops for the expansion of the horizon of their perception about importance of disaster preparedness in India.

\section{References:-}

1. Etymology : http://en.wikipedia.org/wiki/Disaster

2. Tintinali text book of emergency medicine $7^{\text {th }}$ edition section 2 ; chapter 6

3. http://www.unisdr.org/we/inform/terminology

4. http://www.in.undp.org/content/india/en/home/countryinfo/challenges.html

5. M Krajewski, M Sztajnkrycer, A Báez; The Internet Journal of Rescue and Disaster MedicineVolume 4Number 2 http://ispub.com/IJRDM/4/2/4644\#

6. Sheward L, Hunt J, Hagen S, et al. The Relationship Between UK Hospital Nurse Staffing and Emotional Exhaustion and Job Dissatisfaction. J Nurs Manag 2005; 13: 51 - 60.

7. http://www.saarc-sadkn.org/countries/india/disaster_profile.aspx

8. Landesman LY, Leonard RB, SARA three years later. Emergency physician's knowledge, beliefs, and actions. Prehosp Disaster Med. 1993 Jan-Mar;8(1):39-44 ; PMID:10161252 [PubMed - indexed for MEDLINE]

9. Secor-Turner $\mathrm{M}^{1}$, O'Boyle $\mathrm{C}$; Nurses and emergency disasters: what is known. Am J Infect Control. 2006 Sep;34(7):414-20. PMID:16945686;[PubMed - indexed for MEDLINE]

10. Rassin M,et al. Emergency department staff preparedness for mass casualty events involving children;Disaster Manag Response. 2007 Apr-Jun;5(2):36-44.PMID:17517361[PubMed - indexed for MEDLINE]

11. O'Sullivan TL, et al. Canadian nurses' perceptions of preparedness on hospital front lines Prehosp Disaster Med. 2008 May-Jun;23(3):s11-8.PMID:18702283[PubMed - indexed for MEDLINE]

12. Uddin SG et al; Emergency preparedness: addressing a residency training gap: AcadMed.2008 Mar;83(3):298-304.doi:10.1097/ACM.0b013e3181637edc.PMID:18316882 [PubMed indexed for MEDLINE]

13. Rumoro DP et al; A comprehensive disaster training program to improve emergency physicians' preparedness: a 1-year pilot study; Am J Disaster Med. 2010 Nov-Dec;5(6):32531,PMID:21319551[PubMed - indexed for MEDLINE] 